\title{
Hybrid Strategies, Dysfunctional Competition, and New Venture Performance in Transition Economies
}

\author{
Yunzhou Du, ${ }^{1}$ Phillip H. Kim, ${ }^{2}$ and Howard E. Aldrich \\ ${ }^{1}$ Southeast University, China, ${ }^{2}$ Babson College, USA, and ${ }^{3}$ University of North Carolina-Chapel \\ Hill, USA
}

ABSTRACT Conventional wisdom suggests that new ventures can employ a combination of two general strategies to confront the challenges of operating in transition economies or regions known for their weak institutional conditions: These ventures may succeed by enacting a market-orientation strategy, which focuses on providing value to customers and implementing rapid responses to competitive situations. They can also engage in a more traditional political-networking strategy that engages government officials, which may yield public resources and enhance their organizational legitimacy. However, research results are inconclusive regarding the effectiveness of these strategies when they are combined in a hybrid form. We argue that the advantages of a hybrid strategy are contingent on the perception of a specific condition: dysfunctional competition. In our analysis of new venture performance in China, we show that political networking indeed amplifies the positive influence of market-orientation strategies on performance, but only in contexts where dysfunctional competition is perceived to be low. When such competition is high, political networking becomes counterproductive, diverting attention away from swift responses to market demands. By addressing how multiple strategies work together, we offer insights into the extent to which the effectiveness of hybrid strategies - incorporating both market-orientation and political-networking - depend on the context in which they are implemented.

KEYWORDs China's transitional institutions, dysfunctional competition, market-oriented strategies, new venture performance, political networking

\section{INTRODUGTION}

New ventures in transition economies face daunting challenges. In addition to the lack of legitimacy and resources that plague most young firms (Aldrich \& Fiol, 1994; Delmar \& Shane, 2004; Stinchcombe, 1965), they must also cope with weak resource markets (Nee, 1989), uneven legal protections (e.g., Acquaah, 2012; Li \& Qian, 2013), and the severe market-entry barriers typical of weak institutional environments (Lu \& Tao, 2010). To overcome such intimidating 
liabilities, entrepreneurs must execute strategies appropriate for these operating conditions (e.g., Li \& Atuahene-Gima, 2001; Li \& Zhang, 2007). In transition economies such as China, scholars have focused on how new ventures cope with such uncertain conditions, as well as the conditions under which some strategies produce better performance outcomes than others (Li, 2001: 184).

In particular, scholars have examined two types of new venture operating strategies: one focused on market orientation, and the other on political networking. The first line of inquiry has examined the role of market-orientation strategies designed to create competitive advantages by providing superior value and responding rapidly to market conditions (e.g., Narver \& Slater, 1990). The second line of inquiry has focused on the powerful effects of government actions on markets in transition economies and argued that new ventures have a strong incentive to use political-networking strategies to cultivate relations with key officials (e.g., Li \& Zhang, 2007; Tsang, 1996; Xin \& Pearce, 1996). Despite lacking the sway it once held, political networking remains a deeply rooted cultural tradition in many transition economies, wherein personal connections to well-positioned ties are considered a vital business asset (Guo \& Miller 2010). Although market-oriented and politicalnetworking strategies are often posed as a dichotomy, it is more common for new ventures in transition economies to employ the two strategies in combination (e.g., Peng, 2003). However, the performance implications of these 'hybrid strategies' have not been fully examined. We assert that the value of hybrid strategies in transition economies cannot be fully assessed without considering the environments in which they are employed.

In particular, the effectiveness of hybrid strategies for new ventures may hinge on the extent to which entrepreneurs face dysfunctional competition in their markets. Dysfunctional competition refers to the degree to which 'the competitive behavior of firms in a market is opportunistic, unfair, or even unlawful' (e.g., Li \& AtuaheneGima, 2001: 1125). Within transition economies, the level of dysfunctional competition perceived by entrepreneurs can vary both because of actual differences in sector development and due to firms' own subjective interpretations about the nature of their competition (Chen, 1996: 105). Consequently, entrepreneurs may perceive varying levels of dysfunctional competition even within a single industry.

Our theoretical framework integrates the three major concepts we have introduced into a unified argument. We hypothesize that new ventures benefit from using political networking as a complement to a market-orientation strategy only when dysfunctional competition is low. When it is high, however, new ventures lose the complementary benefits of the political-networking strategy. To test our predictions, we examine a sample of Chinese new ventures and find evidence supporting our arguments.

Our work contributes in three ways to the new venture strategy and growth literatures for transition economies. First, with our emphasis on new venture strategies in transition economies, we enlarge the scope of the entrepreneurialgrowth literature by addressing strategies that have been overlooked in studies 
mainly focused on developed economies (e.g., Naldi \& Davidsson, 2014). Second, by examining the effectiveness of a hybrid approach in which new ventures simultaneously deploy market-orientation and political-networking strategies, we expand existing theoretical explanations of market transition, and offer evidence for why certain strategy combinations yield better outcomes. We thus extend the work of previous scholars who explored these concepts in Chinese market transition studies (Jia, You, \& Du, 2012; Li \& Zhang, 2007). Third, our research sheds new light on the relationships between market- and political networking-based strategies and venture performance. We reveal new aspects of these relationships that prior investigations underemphasized because their study designs did not consider the effects of particular environmental contingencies (e.g., Zhou, Li, Zhou, \& Su, 2008).

\section{THEORETICAL DEVELOPMENT AND HYPOTHESES}

New ventures typically struggle to establish themselves as legitimate players offering competitive advantages over more established, better-resourced incumbents (Delmar \& Shane, 2004). Some scholars have argued that new ventures must employ market-oriented (MO) strategies if they wish to succeed (e.g., Jaworski \& Kohli, 1993; Narver \& Slater, 1990). Within transition economies and their weak institutional environments, other scholars have argued that new ventures must use political-networking (PN) strategies to court key government officials (e.g., Li \& Zhang, 2007). However, we note an important contingency for ventures in weak institutional environments: the level of perceived dysfunctional competition (DC) (Li \& Atuahene-Gima, 2001; Sheng, Zhou, \& Li, 2011). Prior research has found independent evidence for the performance effects of all three concepts, taken separately. We offer a synthetic framework incorporating all three factors.

\section{Market-orientation and Political-networking Strategies in Transition Economies}

Following previous studies, we define market-orientation strategies as approaches aimed at creating competitive advantages through simultaneous competitor orientation, customer orientation, and inter-functional coordination (Narver \& Slater, 1990). New ventures emphasizing market orientation in their strategies create competitive advantages by acquiring intelligence on their competitors' strengths and weaknesses, understanding their customers' needs in target markets, and marshaling internal organizational resources to act on such information. Thus, new ventures with a high market orientation offer a compelling value proposition for their customers and formulate rapid responses to competitive actions, either by increasing customer benefits relative to what they pay, or reducing prices charged to customers relative to the benefits they receive (Narver \& Slater, 1990; Porter, 1985).

(C) 2016 The International Association for Chinese Management Research 
In developing economies, some scholars have proposed that new ventures may gain more benefits from a market-orientation strategy if they complement it with a political-networking strategy (Peng, 2003). We define political-networking strategies as actions entrepreneurs take to build and maintain personal ties with government officials to gain favors, especially in political environments lacking strong formal institutions (e.g., Li \& Zhang, 2007; Xin \& Pearce, 1996). According to this view, political networking with government officials can provide new ventures with legitimacy, resources, and regulatory approvals in ways that circumvent formal bureaucratic channels. ${ }^{[1]}$ New ventures can also pursue political networking to solidify market advantages by cultivating favorable state-sponsored monopoly controls (Yang, 2004). If market orientation and political networking were fully complementary as business strategies, then we might expect that firms could simultaneously deploy them as hybrid strategies to enhance their performance, regardless of the operating conditions.

As transition economies such as China have become more market-oriented, the benefits of political networking become problematic and may actually be counterproductive. In fact, several studies have reported increased vulnerabilities created by an emphasis on political networking (Marquis \& Reynard, 2015). Scarce resources must be devoted not only to networking but also to shielding the effort from those who would look upon it unfavorably (e.g., Okhmatovskiy, 2010). In some cases, political networking may actually produce negative effects on performance if new ventures become overly constrained by their political ties and are prevented from responding quickly to market demands or competitors' actions (e.g., Li, Poppo, \& Zhou, 2008). New ventures are unlikely to attain strong and productive political ties at the highest levels of government without significant investments of time and other resources. More realistically, they will have to network with lower-level officials, who may be limited in their ability to provide the full range of benefits the new ventures seek, or deliver them in a timely manner (Okhmatovskiy, 2010). Being highly dependent on political networking also gives government officials opportunities to exert control over the ventures and interfere in venture operations (e.g., Shleifer \& Vishny, 1998). Given the tenuous advantages of cultivating political relationships, firms attempting a hybrid strategy that includes both market orientation and political networking may actually weaken the positive effects of their marketoriented strategies. This may be why prior research has not consistently found a direct positive relationship between network-based strategies and new venture performance (e.g., Luo, Huang, \& Wang, 2012).

Thus, although arguments can be made for the benefits of both individual strategies as well as hybrid approaches, questions remain about the conditions under which we would expect them to be most effective in transition economies. For example, Peng (2003) proposed that new ventures would benefit from hybrid strategies, but empirical research to date has focused only on established firms. Lu et al. (2008) found that a greater emphasis on government networking strengthened the direct positive relationship between customer orientation (as one dimension of 
market orientation) and the performance of established firms in China. However, their results were contradicted by a study of established firms in Taiwan, in which Chung (2011) reported that a greater emphasis on political networking negatively moderated the direct positive effect of market orientation on performance.

Given this mixed set of findings, investigating the effects of hybrid strategies in transition economies without considering environmental contingencies may obscure the actual consequences of employing such strategies. Under some conditions, deploying a political networking strategy may be fully compatible with market-oriented efforts, whereas under others, political networking may undermine a firm's ability to respond to market demands. We turn now to what we argue is a critical environmental contingency of performance outcomes: the extent to which competition within an industry is perceived as dysfunctional.

\section{Operating with Dysfunctional Competition}

During periods of major economic transitions within weak institutional environments, market and legal reforms may not yet be fully implemented throughout all sectors of the economy. New ventures may thus adapt by developing strategies to exploit these inconsistencies, giving rise to a condition referred to as dysfunctional competition, which involves firms engaging in opportunistic, unfair, and unlawful activities vis-à-vis their competitors. In strong institutional environments, such behavior would be monitored and controlled by state institutions. By contrast, weak institutional orders contain neither a dominant legal framework nor the means of enforcing legalities (Kim \& Li, 2014; Tsang, 1996).

A situation can thus arise in which generically weak institutions at the macro-level permit variations in dysfunctional conditions at the meso-level. This could occur within particular industries as firms subjectively perceive competitive conditions, or more objectively across different industrial sectors (Chen, 1996). We highlight this distinction to explain how new ventures can perceive different levels of dysfunctional competition even within a single nation. Explicitly differentiating the venture, industry, and societal levels of influence calls our attention to how hybrid strategies may operate with varying degrees of success within or across different industrial sectors. This framework raises the possibility that the net effects of hybrid strategies on performance may be obscured unless we analyze the full set of component influences.

Over time, as societies adopt reforms based on market principles, the average level of dysfunctional competition would be expected to decline as macrolevel market-based institutions are enacted and enforced. However, the pace of reform is not uniform throughout society (e.g., Li \& Qian, 2013), and levels of dysfunctional competition often vary across sectors. In sectors slow to adopt reforms, dysfunctional competition will persist. Without constraints from normative institutions, opportunistic behavior runs rampant, harming new ventures unprepared for these operating conditions (Li \& Zhang, 2007; Sheng et al., 2011). 
Given the variations produced by uneven market-reform adoptions and differences in perceptions of them, new ventures may respond by enacting different combinations of market-oriented and political-networking strategies. Following in the tradition of strategy scholars, we argue that new ventures determine their strategy choices based on their perceptions of their operating environment since 'awareness is considered a prerequisite for any move' (Chen, 1996: 110). Potential business opportunities are created and pursued, in part, by what entrepreneurs perceive as the underlying problems or needs insufficiently addressed by the market (Tuggle \& Gerwin, 1980: 576). Part of this assessment also applies to the competitive landscape, as entrepreneurs will perceive different levels of dysfunctional competition.

To the extent that perceived dysfunctional competition varies across firms, we expect differences in the effects of hybrid strategies on new venture performance. We construct a three-way moderating framework based on three constructs: market orientation (MO), political networking (PN), and dysfunctional competition (DC). Three-way moderation arguments can be presented in different ways. For our study, we followed the approach used by Stam and Elfring (2008) who argued for a two-way $\left(\mathrm{X}_{1} * \mathrm{X}_{2}\right)$ moderation at different levels of a third condition $\left(\mathrm{X}_{3}\right)$ - a format conducive for conveying our multifaceted reasoning. Given the complexities of articulating a three-way moderation argument and because we expect different configurations of relationships in the two conditions we analyze, we divide our explanation into two parts that correspond to our two study predictions: the performance effects of hybrid strategies at low $(\mathrm{H} 1)$ and high $(\mathrm{H} 2)$ levels of dysfunctional competition. We present our reasoning for how the bivariate MO-PN moderation operates within each level. Figures la \& 1b summarize our moderating framework.

\section{Hybrid Strategies in Contexts with Low Dysfunctional Competition}

We first examine the MO-PN relationship on performance outcomes in contexts with low levels of perceived dysfunctional competition. In these environments, entrepreneurs perceive that their competitors will be more likely to play by the rules and not engage in deceptive or illegal practices. We expect to see a positive benefit from hybrid strategies in such contexts: political networking strengthening the direct positive relationship between a new venture's market orientation and its performance (see Figure la, Relationship H1). We offer three reasons for this prediction about political networking's contingent benefits: 1) improved access to resources, 2) greater informational advantages, and 3) an increased likelihood of gaining legitimacy. Producing these benefits takes time, as relationships with government officials become more important as officials rise through the bureaucratic ranks. Operating in a fair competitive environment provides new ventures with additional time to cultivate their key relationships. Thus, political networking's enhancement of a market-oriented strategy on performance 


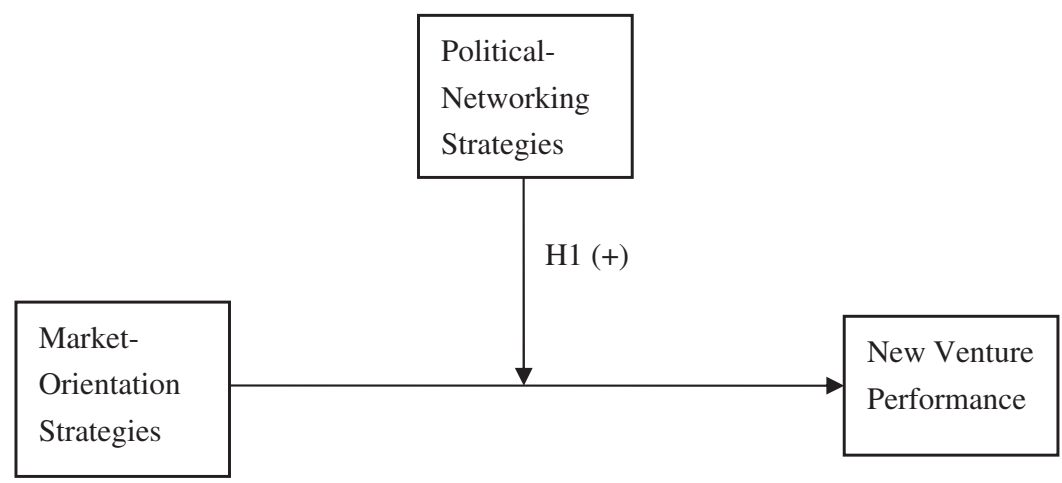

(a)

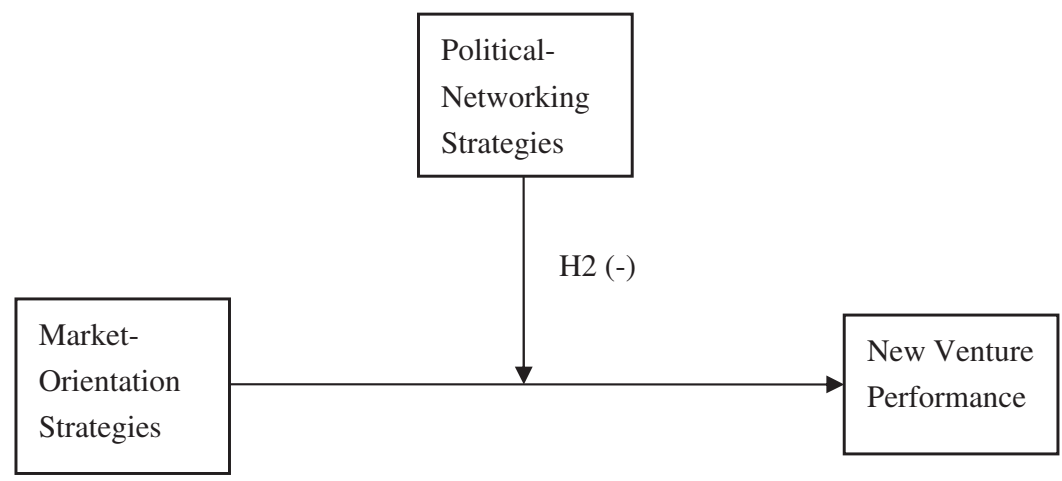

(b)

Figure 1 (a) Positive moderating influence of political networking on the market orientation and newventure-performance relationship at low levels of dysfunctional competition. (b) Negative moderating influence of political networking on the market orientation and new-venture-performance relationship at high levels of dysfunctional competition.

is contingent on relatively stable operating conditions or when dysfunctional competition is low.

Many of the standard arguments about the role of political networking in transition economies apply to our assertion about its positive moderating influence on market-oriented strategies in stable, legal operating contexts. In these more predictable conditions, new ventures will enhance their market-oriented strategies by seeking both resources and information through their connections with government officials (Funk \& Hirschman, forthcoming). Such ties are vital because in generally weak institutional environments, underdeveloped factor markets make acquiring resources through conventional means more difficult (Hoskisson et al., 2000; Nee, 1989), requiring new ventures to seek other mechanisms for the private exchange of resources (e.g., Li \& Zhang, 2007; Peng et al., 2008). As a result, in many developing economies, governments are still a key ally to businesses, because they retain considerable control over resource distribution. For example, acquiring land for new Chinese ventures cannot be accomplished without government involvement 
because all land is either state- or collectively owned. Having relationships with key officials who can distribute these resources and approve projects enhances the value of a new venture's market-oriented strategy (Xin \& Pearce, 1996). Additionally, as a result of their relationships, new ventures may receive preferential treatment for government grants through state-owned banks (Acquaah, 2012; Li \& Zhang, 2007). Within relatively stable operating conditions, this access to resources amplifies the benefits of market-oriented strategies on performance because political-networking efforts complement actions to exploit market opportunities (Funk \& Hirschman, forthcoming).

Related to accessing resources, cultivating political ties in transition economies also strengthens the influence of market-oriented strategies on performance because it allows entrepreneurs to establish a more reliable channel for acquiring information (Li \& Zhang, 2007; Luo, 2003). This complementary approach is also most useful in contexts with low levels of dysfunctional competition. New ventures are often unable to acquire accurate information about business conditions through public means because published information is inconsistent or inaccurate. Given that successful market orientation depends on making strategic decisions based on timely and accurate knowledge, new ventures can benefit from access to better quality information (Yang, 2004). In other situations, political ties may disclose information about market opportunities unknown to the general public, further strengthening the positive influence of market-oriented strategies on performance (Bradley, Aldrich, Shepherd, \& Wiklund, 2011: 488). The accuracy of, and advantages from, receiving this information on exploiting market opportunities improves with fairer, more stable operating conditions.

Finally, political networking also enhances a new venture's market orientation by overcoming legitimacy obstacles for its operations (Peng, 2003). Given the uncertainties of operating in an environment with underdeveloped laws and unclear regulatory guidelines, having ties to government officials can help new ventures gain competitive advantages in the marketplace (Aldrich \& Ruef, 2006). These assurances work best when new ventures can reasonably anticipate future market conditions without worrying about reckless actions from their competitors. For example, when regulations are ambiguous, local governments are able to take advantage of the lack of formal details overseeing these laws and exert more power in levying taxes, duties, and other unexpected fees on new ventures. However, having strong relationships with key officials can shield new ventures from these concerns (Tsang, 1996). Through political networking, new ventures can gain tacit support and protection from the vagaries in the law produced by weak institutional environments (e.g., Peng et al., 2008). 'Who you know' is a signal of 'who is whose whom', a Chinese principle known as baohusan (literally, 'protective umbrella'). As a result, in low dysfunctional competitive conditions, this legitimacy magnifies the effects of market-oriented strategies on performance.

To summarize our rationale for the positive moderating influence of political networking on a new venture's market orientation and performance: when 
dysfunctional competition is perceived as low, gaining legitimacy, resources, information, and government protection is key in helping new ventures prosper. Because new ventures in this operating context are less concerned about the illegal practices of their competitors, they can devote more resources to monitoring market conditions and coordinating their political networking with other strategic and competitive practices. For these reasons, we posit:

\section{Hypothesis 1: At low levels of dysfunctional competition, the positive relationship between market orientation and new venture performance will strengthen for ventures placing a greater emphasis on political networking as compared to ventures placing less of an emphasis on political networking.}

\section{Hybrid Strategies in Contexts with High Dysfunctional Competition}

Although political networking can be beneficial to new venture performance, it also has its disadvantages (e.g., Marquis \& Reynard, 2015; Sun, Mellahi, \& Wright, 2012). We argue that in some conditions, these disadvantages overshadow potential benefits. We posit that in highly dysfunctional operating environments, a greater emphasis on political-networking strategies actually weakens the positive effect of market orientation on performance (see Figure 1b, Relationship H2). For example, when competing firms do not follow official regulations, the potential information advantage gained from political networking may not benefit a firm as much as in more stable environment. Moreover, the legitimacy gained from political networking may be of lesser importance, because many firms in the market lack legitimacy to begin with, as violators of existing regulations. Consequently, the cost of over-dependence on networking can exceed its few benefits, resulting in hybrid strategies that diminish the direct and positive influence of market-oriented strategies on performance.

We offer three reasons for this negative moderating influence: 1) extensive free-riding and opportunistic behaviors by competitors in highly dysfunctional environments disrupt the positive moderating influence of political networking on market-oriented strategies, 2) in highly dysfunctional environments, competitors can more easily produce similar goods without fear of government monitoring or intervention, and 3) because of their over-embeddedness in political relationships, new ventures lose the ability to react quickly to competitive threats and new information while still incurring costs to nurture these relationships. All of these reasons can be linked to the heightened risks produced by hybrid strategies that overemphasize political networking in highly dysfunctional competitive landscapes.

In weak institutional contexts with severe dysfunctional competition, new ventures will perceive serious threats from rivals engaging in unfair actions, such as counterfeiting products or imitating proprietary practices. Although political networking with government officials may lead to some enforcement or protection against unfair practices in the long-term, rivals can simply disregard these threats in 
the short-term. Competitors can overlook regulations governing market behaviors and act opportunistically as 'free riders' by copying existing products and marketing them as their own in unstable appropriability regimes (Lieberman \& Montgomery, 1998; Teece, 1986). In some regions of China, these actions occur regularly as firms strive to out-compete each other by brazenly copying product features. For example, in the Shenzhen region of China, Shanzhai products are manufactured as lower-cost imitations of industry leaders. (Shanzhai is a commonly used term used for Chinese imitated goods [Hu, Wan, \& Zhu, 2011].) With a low-cost, low-price market strategy, they can easily threaten the legitimate share of any new venture by illegally appropriating its intellectual property rights.

With lax legal protections and enforcement, new ventures attempt to rectify this by reaching out to government officials to thwart unfair competitive practices. Other ventures may increase their political networking efforts to seek out governmentbacked business opportunities that are better sheltered from the harsh competitive pressures in dysfunctional conditions. If these ventures can secure exclusive rights to a certain region, industry, or other classification, they may be able to minimize their dependence on pursing opportunities with only market-oriented strategies. However, achieving these desired outcomes likely involves cultivating relationships with highest-ranked officials, which requires time and resources that would be diverted from addressing competitive conditions. Although some may develop such relationships, more realistically, most ventures will likely maintain access to only lower-level officials, whose influence may be insufficient in a difficult competitive landscape. This misalignment between what political networking can provide and the realities of a highly dysfunctional competitive context detracts from the benefits of market-oriented strategies on performance (cf., Gu, Hung, \& Tse, 2008; Nee, 1989: 677). Thus, investing in political networking to acquire information and legitimacy does not always yield tangible advantages.

Without effective legal protections or enforcement mechanisms at their disposal, the benefits of a new venture's market orientation then depend on its ability to introduce products rapidly, service its customers responsively, and make strategic changes well before their underhanded competitors do (Eisenhardt, 1989). Speed is of the essence when confronting unpredictable operating conditions. New ventures dependent on innovative products need to accelerate the pace of releasing productline extensions because they cannot rely on a government-enforced appropriability regime to protect them (Li \& Qian, 2013; Teece, 1986).

Given the need to react swiftly to these fast-paced rival actions in highly dysfunctional competitive situations, a new venture's ability to maintain the necessary market orientation will be hampered if it places too great an emphasis on political networking. A chief concern is that they are more likely to lose their strategic autonomy in their dealings with the government (Bradley et al., 2011; Uzzi, 1997). This tradeoff has several consequences for new venture strategies: a reduction in flexibility, a decline in the diversity of options, and a loss of speed when executing these options (Nadkarni \& Narayanan, 2007). When new ventures 
devote attention to cultivating political ties, they also increase their social obligations to these officials (e.g., Li et al., 2008). The loss of strategic autonomy and added social obligations temper any benefits that political ties offer to new ventures when competition is dysfunctional and unpredictable.

At the exact moment when new ventures require rapid responses to their competition, they can find themselves trapped in their own relationships, unable to adequately respond to shifts in market demands and hampered in their ability to improve (Li et al., 2008: 388; cf. Mitchell \& Singh, 1996). Referred to by some scholars as a 'collective blindness', this dilemma results from being indebted to political networks (e.g., Gu, Hung, \& Tse, 2008). The same collective blindness affecting competitive responses also limits a new venture's access to new ideas and diverse information from outside their local network (Ma, 2015; Okhmatovskiy, 2010; Uzzi, 1997). Just when ventures ought to concentrate their efforts on defending against competitive threats, an overemphasis on political networking drains their resources. Cultivating these relationships is not a one-time affair. They require constant nurturing and ongoing investments into 'unreciprocated gifts', regardless of whether any benefits are generated (Xin \& Pierce, 1996). When new ventures heavily depend on certain officials for their support, these ventures expose themselves to the political risk caused by shifting market and legal practices - a substantial liability for those operating in unstable institutional environments such as China (Nee, 1992). The inability to respond quickly to market conditions the most fundamental strategy for firms facing highly dysfunctional competition and the costs of nurturing political relationships diminish the positive benefits of market-oriented strategies.

We summarize our reasoning for the three-way moderation in contexts where dysfunctional competition is high. Excessive reliance on political networking constrains new ventures' flexibility for making strategic changes, accessing new ideas and pertinent information, and exploiting opportunities in fast-paced competitive environments. These restrictions inhibit firms' ability to capitalize on their market orientation and also weaken these direct benefits when in pursuit of improved performance. The downsides of political networking wipe out any benefits in highly dysfunctional operating contexts. For these reasons, we predict:

Hypothesis 2: At high levels of dysfunctional competition, the positive relationship between market orientation and new venture performance will weaken for ventures placing a greater emphasis on political networking as compared to ventures placing less of an emphasis on political networking.

\section{METHOD}

\section{Sampling and Data Collection}

To test our hypotheses, we created a study sample of Chinese ventures and surveyed the entrepreneurs in these new firms about characteristics related to our theoretical 
Table 1. Characteristics of venture sample

\begin{tabular}{lrr}
\hline \hline Venture Characteristics & Frequency & $\%$ \\
\hline Venture size & & \\
$\quad<10$ employees & 33 & 16.2 \\
$10-29$ & 70 & 34.3 \\
$30-79$ & 57 & 27.9 \\
80-199 & 19 & 9.3 \\
>200 employees & 25 & 12.3 \\
Ownership & & \\
Private enterprise & 152 & 72.7 \\
$\quad$ Stated-owned & 3 & 1.4 \\
Foreign wholly owned & 17 & 8.1 \\
International joint venture & 32 & 15.3 \\
Others & 4 & 1.9 \\
Industry Type & & \\
Information technology & 80 & 38.3 \\
Others & 129 & 61.7 \\
Technology-focused enterprises & & \\
Technology ventures & 112 & 53.6 \\
Non-technology ventures & 97 & 46.4 \\
Locations & & \\
Beijing & 158 & 75.6 \\
Others & 51 & 24.4 \\
\hline \hline
\end{tabular}

arguments. We followed data-collection principles established in published studies on new venture performance in transition economies (e.g., Li \& Zhang, 2007; McDougall, Covin, Robinson, \& Herron, 1994). We formed our sample using a directory compiled by Beijing Ebuywww - an established Chinese survey research firm. Our sample was drawn from their database of nearly 800,000 new ventures (including about 60,000 located in Beijing). As an experienced research firm, Beijing Ebuywww compiled their new venture database from two high-quality sources the National Bureau of Statistics of China's Economic Census and the Census of Basic Units - and supplemented them with industrial and commercial registration data. We also benefited from using its regularly updated database and relatively complete new-venture directory to form our sample. For our sampling frame, we defined new ventures as eight years old or younger, based on the firm's legal registration and data collection year. We analyzed 900 new ventures meeting these criteria randomly sampled by the research firm from its new venture database. To maximize sample representativeness at a reasonable cost, we requested the research firm to produce a sample containing 600 ventures from Beijing and 300 located elsewhere in China. ${ }^{2]}$ To ensure adequate coverage and variation in our theoretical constructs, we verified that our sample contained new ventures representing a range of sizes, ownership types, industries, technology focus, and locations (see Table 1). These characteristics are important in China's transition economy and have been shown to be associated with dysfunctional competition 
and political-networking strategies (e.g., Li \& Atuahene-Gima, 2001; Li \& Zhang, 2007).

We gathered information from these ventures between October 2009 and June 2010. To collect our survey data, we mailed, faxed, or emailed questionnaires to a senior manager in each new venture. As key informants, these entrepreneurs are assumed to be able to provide valid and reliable information about their businesses in ways allowing us to assemble these data in a cost-effective manner. To increase participation, we also offered to provide respondents a summary of the research findings. After several communications by e-mail and/or phone, we received 230 completed questionnaires; 21 were declared ineligible because of incomplete responses, netting a final sample of 209 questionnaires for our analyses. The effective questionnaire response rate was 23.2 percent, which is comparable to other general organizational research using mail surveys from senior managers (Baruch \& Holtom, 2008) and specifically to other studies on new venture performance (McDougall et al. [1994]: 11 percent response rate; and Shane and Cable [2002]: 24 percent). For further assurance, we checked for non-response bias in terms of venture age, size, location, and industry between those that responded with those that did not (Li \& Zhang, 2007). We found no evidence that non-response bias affected our results. ${ }^{[3]}$

To enhance survey reliability and validity, we took the following steps. First, we used scales published in reputable academic journals. Second, we used the backtranslation method to reduce the bias of language and cultural differences (Brislin, 1980). Specifically, we translated the English version of the scales into Chinese and then two experts in our research field conducted the back-translation. Third, we invited business practitioners to evaluate and provide feedback regarding the scale measurements' face validity. Last, we partnered with our survey research company, Beijing Ebuywww, which has significant experience in fielding highquality academic surveys with effective response rates.

\section{Dependent Variable}

We measured new venture performance (NVP) with a scale adapted from $\mathrm{Li}$ and Atuahene-Gima (2001). The scale is based on performance metrics such as return on sales, profit growth, overall operation efficiency, sales growth, market-share growth, and the firm's overall marketplace reputation (see Appendix A.1 for details). Using these metrics, respondents were asked to evaluate their venture's performance in the past three years on 5-point scale, with 1 representing 'worse' and 5 representing 'much better' (compared with their main competitors). We conducted a confirmative factor analysis (CFA) on this scale. The CFA indicated a good fit for the NVP scale as a single factor $\left(\chi^{2}=10.42, \mathrm{df}=9, \chi^{2} / \mathrm{df}<2\right.$, RMSEA $=0.03, \mathrm{NNFI}=0.99, \mathrm{CFI}=0.99, \mathrm{IFI}=0.99) .{ }^{[4]}$ The alpha reliability coefficient for performance was 0.82 . 


\section{Independent Variables}

To form the market-orientation variable, we adapted a scale developed by Narver and Slater (1990). This scale contains eleven items measuring three dimensions: competitor orientation (five items), customer orientation (three items), and interfunctional orientation (three items). The entrepreneurs were asked to respond to the scale-item questions based on their ventures' activities in the past three years. All of the items were measured using a 5-point scale anchored by 1 for 'strongly disagree' and 5 for 'strongly agree'. Our CFA fit indexes supported the three-factor structure of market orientation $\left(\chi^{2}=86.11, \mathrm{df}=39, \chi^{2} / \mathrm{df}<2.21, \mathrm{RMSEA}=\right.$ $0.08, \mathrm{NNFI}=0.97, \mathrm{CFI}=0.98, \mathrm{IFI}=0.98)$. The alpha reliability coefficient for the entire market-orientation construct was 0.89 .

For the political-networking variable, we adapted the scale used by Xin and Pearce (1996) and Li and Atuahene-Gima (2001). Our questions asked about the extent to which venture founders spent effort cultivating relationships with government officials and agencies in the past three years. All three items were measured using 5-point scales, with 1 meaning 'to no extent' and 5 meaning 'to a great extent'. The alpha reliability coefficient for political networking was 0.75 .

The dysfunctional-competition variable was based on a scale developed by $\mathrm{Li}$ and Atuahene-Gima (2001) for the Chinese context. It captures the extent to which the ventures perceived the following problems in their principal industries in the past three years: counterfeiting of the firm's products and trademarks, ineffective market competition laws to protect intellectual property, and increased unfair competitive practices in the industry. We employed this subjective measure since managers take strategic actions based on their awareness and perception of their external operating environments (Chen, 1996; Tan \& Litsschert, 1994; Tuggle \& Gerwin, 1980: 576). Dysfunctional competition was measured on a scale of 1 to 5 (with 1 meaning 'to no extent' and 5 meaning 'to a great extent'). The alpha coefficient for this construct was 0.71 .

For all these scales, we averaged the items of each latent variable to produce measurement scores based on widely accepted principles from classical measurement theory used in management research (Edwards, 2003). We used these scores in our multivariate analyses. We provide more details about all these measures in Appendix A.1.

\section{Validity and Composite Reliability}

As an additional check on our scale measures' convergent and discriminant validity and reliability, we conducted two more diagnostics (see Appendix A.2). First, we ran another CFA, but this time, with all four scales treated as multi-item latent variables (market orientation, political networking, dysfunctional competition, and new venture performance). Since these measures are latent variables with multiple 
dimensions and contain more than five items, we used the item-parceling technique, treating the three market-orientation dimensions as indicators and randomly averaging the six performance items as three sets of indicators (Kenny, 2012; Wang et al., 2005). The CFA results showed that a four-factor model fit the data well $\left(\chi^{2}=\right.$ 86.57, $\mathrm{df}=48, \chi^{2} / \mathrm{df}<2, \mathrm{RMSEA}=0.06, \mathrm{NNFI}=0.94, \mathrm{CFI}=0.96, \mathrm{IFI}=0.96$ ) (Hair et al. 1998: 634-635). The composite reliabilities for market orientation, political networking, dysfunctional competition, and new venture performance $(0.88,0.78,0.71$, and 0.83 , respectively) were over the acceptable value of 0.70 (e.g., Hair et al., 1998: 636). Next, we calculated the average variance extracted (AVE) from our four multi-item latent variables. The AVEs for market orientation, political networking, dysfunctional competition and new venture performance $(0.72,0.56,0.46$, and 0.63 , respectively) were much larger than the squared values of pairwise correlations between each of the four latent constructs. The largest correlation existed between market orientation and performance $\left(r=0.35 ; r^{2}=\right.$ 0.12). Three of four AVEs of latent variables were higher than the benchmark of 0.50 (Fornell \& Larcker, 1981); the third variable, dysfunctional competition, had an AVE near 0.50. These checks reassured us of testing our theoretical arguments with valid and reliable measures consistent with commonly accepted guidelines (e.g., Hair et al., 1998: 636; Wang, Law, Hackett, Wang, \& Chen, 2005: 427).

\section{Interaction Variables}

We formed interaction variables by taking cross-products of the independent variables. To decrease multicollinearity in our regression analysis, we standardized the market-orientation, political-networking, and dysfunctional-competition variables before creating interaction terms.

\section{Control Variables}

To account for alternative explanations, we controlled for several other venture characteristics: venture age (in years), venture size (natural log of the number of employees), location (Beijing $=1$, other cities $=0)^{[5]}$, industry (information-technology industry $=1$, other sectors $=0)$, technology-focused venture $(1=$ yes $)$, private ownership $(1=$ yes), environmental hostility (a scale-based measure of the firm's task environment based on Miller (1987), composite reliability $=0.73)$, regional market development measured as NERI index of marketization of China's provinces (Fan, Wang, \& Zhu, 2010), entrepreneurial orientation (Covin \& Slevin, 1989), and institutional support (Li \& Atuahene-Gima, 2001). The scales are described in Appendix A.1. These control variables are similar to those used in prior studies on venture performance in transition economies (e.g., Li \& Zhang, 2007). 


\section{Model Diagnostics}

Given the survey design, we also investigated the possibility of common method bias (CMB) in our findings. First, CMB typically exists when high correlations exist among all variables (Siemsen, Roth, \& Oliveira, 2010: 472, quoted by Reinholt, Pedersen, \& Foss, 2011: 1283; Spector, 2006: 224). We found no evidence of high correlations. Second, we used the Harman one-factor test method (Podsakoff \& Organ, 1986) for additional insights into this concern. Exploratory factor analysis (EFA) results showed that extracting a six-factor model accounted for 65 percent of the total variance, in which the first factor only explained a small portion (25 percent), minimizing the chances of serious common method bias in our findings. Third, we compared results between three nested models produced by the CFA: a one-factor model, a two-factor model with market orientation and performance as the factors, and a three-factor model which added a third common method factor to the existing two (Podsakoff, MacKenzie, Lee, \& Podsakoff, 2003). This technique allowed us to determine if the model with the common method factor produced a better fit than the others. The two-factor model performed better than the one-factor model in the chi-square test $(\triangle \chi 2[\mathrm{n}=187, \triangle \mathrm{df}=17]=420.24$, $\mathrm{p}<0.001 ; \mathrm{RMSEA}=0.08, \mathrm{NNFI}=0.95, \mathrm{CFI}=0.96, \mathrm{IFI}=0.96)$, while the three-factor model did not significantly improve the model's fit $(\triangle \chi 2[n=187$, $\Delta \mathrm{df}=3]=0.02 ; \mathrm{p}<0.25)$. Fourth, it is highly unlikely for respondents to predict a three-way interaction theoretical model and thus, unrealistic to attribute our results to CMB (Aiken \& West, 1991; Zhang \& Li, 2010). Finally, we used the markervariable method, a stringent test of CMB developed by Lindell and Whitney (2001) and Malhotra, Kim, and Patil (2006) to further assess any CMB concerns. This method also showed minimal effects of $\mathrm{CMB}$ on our results even after conducting additional sensitivity tests recommended by Malhotra et al. (2006). In sum, these additional checks helped rule out any concerns that common method bias was a serious problem in our study.

\section{RESULTS}

We report descriptive results (means, standard deviations, correlations, and scale alpha coefficients) in Table 2. All VIFs were lower than 2 in our regression models, indicating little possibility of multicollinearity problems.

In terms of our multivariate analyses, we tested our predictions using OLS regression. We report the results of this analysis in Table 3. We began this analysis with just control variables (Model 1), first-order main effects (Model 2), and two-way interaction effects of market orientation, political networking, and dysfunctional competition on new venture performance (Model 3-5). We note two baseline findings from these preliminary models: For the first-order results, strength of market orientation is positively associated with new venture performance (Model 2). For the two-way interaction results, it is useful to note the positive interaction 
Table 2. Mean, standard deviation, and correlations

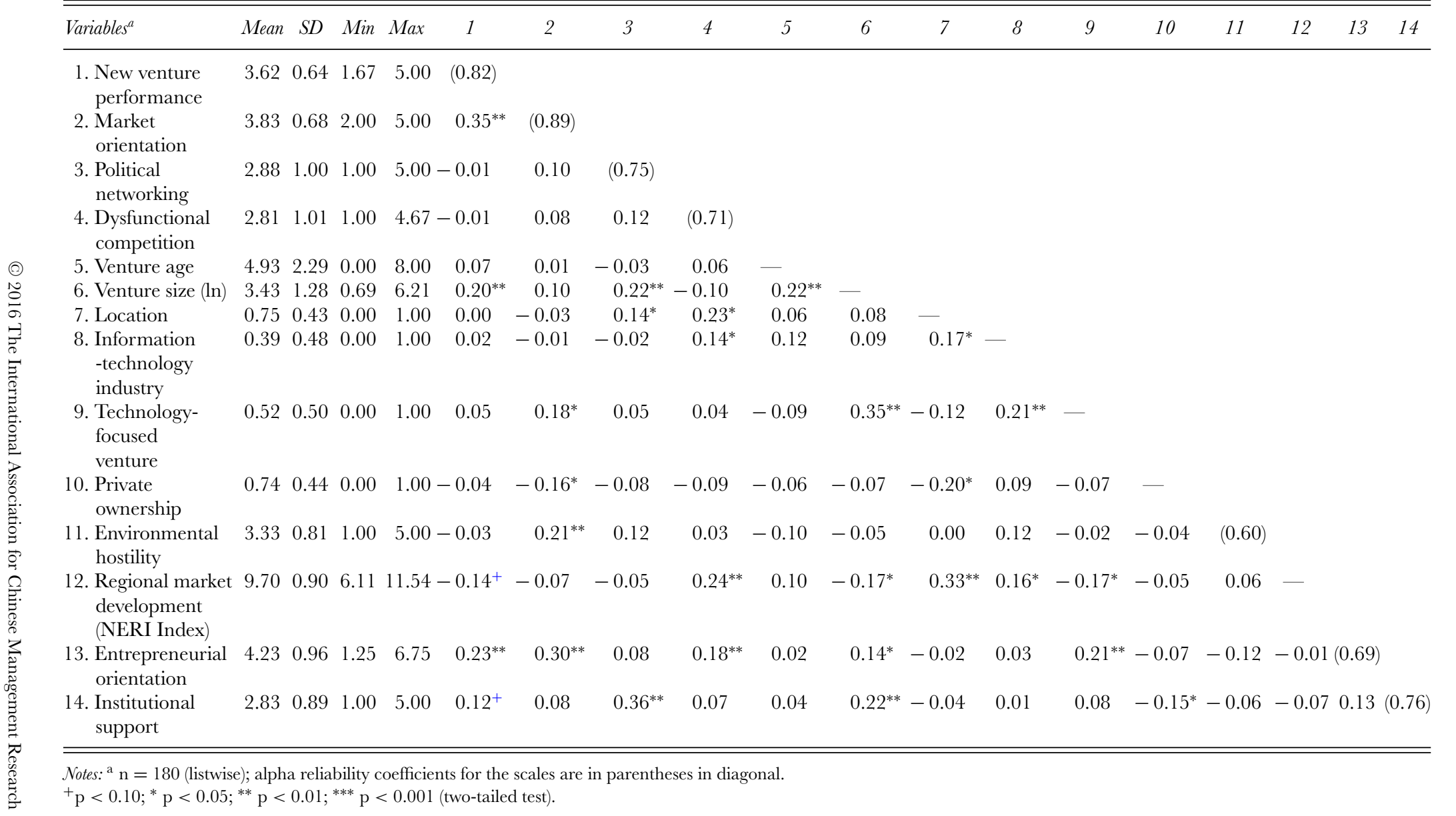


Table 3. Three-way interaction effect of market orientation, political networking, and dysfunctional competition on new venture performance

\begin{tabular}{|c|c|c|c|c|c|c|c|}
\hline \multirow[b]{2}{*}{ Variables } & \multicolumn{7}{|c|}{ New venture performance $e^{a, b}$} \\
\hline & Model 1 & Model 2 & Model 3 & Model 4 & Model 5 & Model 6 & 2SLS Model \\
\hline Constant & $\begin{array}{l}3.525^{* * *} \\
(0.107)\end{array}$ & $\begin{array}{l}3.508^{* * * *} \\
(0.106)\end{array}$ & $\begin{array}{l}3.499^{* * *} \\
(0.106)\end{array}$ & $\begin{array}{l}3.501^{* * *} \\
(0.105)\end{array}$ & $\begin{array}{l}3.494^{* * *} \\
(0.106)\end{array}$ & $\begin{array}{l}3.473^{* * *} \\
(0.103)\end{array}$ & $\begin{array}{l}3.487^{* *} \\
(0.110)\end{array}$ \\
\hline Venture age & $\begin{array}{c}0.039 \\
(0.052)\end{array}$ & $\begin{array}{c}0.022 \\
(0.050)\end{array}$ & $\begin{array}{c}0.030 \\
(0.050)\end{array}$ & $\begin{array}{c}0.033 \\
(0.050)\end{array}$ & $\begin{array}{l}0.037 \\
(0.051)\end{array}$ & $\begin{array}{c}0.043 \\
(0.049)\end{array}$ & $\begin{array}{l}0.035 \\
(0.052)\end{array}$ \\
\hline Venture size (ln) & $\begin{array}{c}0.084 \\
(0.055)\end{array}$ & $\begin{array}{l}0.102^{+} \\
(0.054)\end{array}$ & $\begin{array}{c}0.112^{*} \\
(0.054)\end{array}$ & $\begin{array}{c}0.110^{*} \\
(0.053)\end{array}$ & $\begin{array}{l}0.115^{*} \\
(0.054)\end{array}$ & $\begin{array}{c}0.097^{+} \\
(0.053)\end{array}$ & $\begin{array}{l}0.089 \\
(0.056)\end{array}$ \\
\hline Location & $\begin{array}{c}0.124 \\
(.122)\end{array}$ & $\begin{array}{c}0.142 \\
(0.123)\end{array}$ & $\begin{array}{l}0.146 \\
(0.123)\end{array}$ & $\begin{array}{c}0.122 \\
(0.122)\end{array}$ & $\begin{array}{l}0.127 \\
(0.123)\end{array}$ & $\begin{array}{c}0.104 \\
(0.119)\end{array}$ & $\begin{array}{c}0.055 \\
(0.133)\end{array}$ \\
\hline Information-technology industry & $\begin{array}{r}-0.004 \\
(0.104)\end{array}$ & $\begin{array}{r}-0.006 \\
(0.099)\end{array}$ & $\begin{array}{r}-0.009 \\
(0.099)\end{array}$ & $\begin{array}{l}0.015 \\
(0.098)\end{array}$ & $\begin{array}{l}0.018 \\
(0.099)\end{array}$ & $\begin{array}{c}0.072 \\
(0.097)\end{array}$ & $\begin{array}{c}0.102 \\
(0.106)\end{array}$ \\
\hline Technology-focused venture & $\begin{array}{r}-0.030 \\
(0.054)\end{array}$ & $\begin{array}{r}-0.059 \\
(0.052)\end{array}$ & $\begin{array}{r}-0.061 \\
(0.051)\end{array}$ & $\begin{array}{r}-0.053 \\
(0.051)\end{array}$ & $\begin{array}{r}-0.053 \\
(0.051)\end{array}$ & $\begin{array}{r}-0.048 \\
(0.049)\end{array}$ & $\begin{array}{r}-0.067 \\
(0.054)\end{array}$ \\
\hline Private ownership & $\begin{array}{r}-0.005 \\
(0.050)\end{array}$ & $\begin{array}{c}0.013 \\
(0.048)\end{array}$ & $\begin{array}{c}0.010 \\
(0.048)\end{array}$ & $\begin{array}{c}0.007 \\
(0.047)\end{array}$ & $\begin{array}{c}0.003 \\
(0.048)\end{array}$ & $\begin{array}{c}0.016 \\
(0.047)\end{array}$ & $\begin{array}{c}0.035 \\
(0.053)\end{array}$ \\
\hline Environmental hostility & $\begin{array}{r}-0.001 \\
(0.051)\end{array}$ & $\begin{array}{r}-0.044 \\
(0.050)\end{array}$ & $\begin{array}{r}-0.042 \\
(0.050)\end{array}$ & $\begin{array}{r}-0.050 \\
(0.050)\end{array}$ & $\begin{array}{r}-0.050 \\
(0.050)\end{array}$ & $\begin{array}{r}-0.042 \\
(0.048)\end{array}$ & $\begin{array}{r}-0.089 \\
(0.064)\end{array}$ \\
\hline Regional market development & $\begin{array}{r}-0.124^{*} \\
(0.053)\end{array}$ & $\begin{array}{r}-0.109^{*} \\
(0.051)\end{array}$ & $\begin{array}{r}-0.113^{*} \\
(0.051)\end{array}$ & $\begin{array}{r}-0.118^{*} \\
(0.050)\end{array}$ & $\begin{array}{r}-0.122^{*} \\
(0.051)\end{array}$ & $\begin{array}{c}-0.131^{* *} \\
(0.050)\end{array}$ & $\begin{array}{r}-0.121^{*} \\
(0.053)\end{array}$ \\
\hline
\end{tabular}


Table 3. (Continued) Three-way interaction effect of market orientation, political networking, and dysfunctional competition on new venture performance

\begin{tabular}{|c|c|c|c|c|c|c|c|}
\hline \multirow[b]{2}{*}{ Variables } & \multicolumn{7}{|c|}{ New venture performance $e^{a, b}$} \\
\hline & Model 1 & Model 2 & Model 3 & Model 4 & Model 5 & Model 6 & 2SLS Model \\
\hline Entrepreneurial orientation & $\begin{array}{c}0.113^{*} \\
(0.051)\end{array}$ & $\begin{array}{c}0.051 \\
(0.051)\end{array}$ & $\begin{array}{c}0.060 \\
(0.052)\end{array}$ & $\begin{array}{c}0.055 \\
(0.051)\end{array}$ & $\begin{array}{c}0.058 \\
(0.052)\end{array}$ & $\begin{array}{c}0.054 \\
(0.050)\end{array}$ & $\begin{array}{r}-0.009 \\
(0.075)\end{array}$ \\
\hline Institutional support & $\begin{array}{c}0.038 \\
(0.050)\end{array}$ & $\begin{array}{c}0.038 \\
(0.050)\end{array}$ & $\begin{array}{c}0.029 \\
(0.050)\end{array}$ & $\begin{array}{c}0.029 \\
(0.050)\end{array}$ & $\begin{array}{c}0.028 \\
(0.050)\end{array}$ & $\begin{array}{c}0.043 \\
(0.048)\end{array}$ & $\begin{array}{c}0.031 \\
(0.052)\end{array}$ \\
\hline Market orientation & & $\begin{array}{l}0.221^{\text {*** }} \\
(0.050)\end{array}$ & $\begin{array}{l}0.214^{* * *} \\
(0.050)\end{array}$ & $\begin{array}{l}0.234^{* * *} \\
(0.051)\end{array}$ & $\begin{array}{l}0.234^{* * *} \\
(0.051)\end{array}$ & $\begin{array}{l}0.271^{* * *} \\
(0.050)\end{array}$ & $\begin{array}{c}0.479^{* *} \\
(0.184)\end{array}$ \\
\hline Political networking & & $\begin{array}{r}-0.068 \\
(0.053)\end{array}$ & $\begin{array}{r}-0.073 \\
(0.053)\end{array}$ & $\begin{array}{r}-0.058 \\
(0.053)\end{array}$ & $\begin{array}{r}-0.058 \\
(0.053)\end{array}$ & $\begin{array}{r}-0.053 \\
(0.052)\end{array}$ & $\begin{array}{r}-0.041 \\
(0.055)\end{array}$ \\
\hline Dysfunctional competition & & $\begin{array}{r}-0.005 \\
(0.047)\end{array}$ & $\begin{array}{c}0.002 \\
(0.047)\end{array}$ & $\begin{array}{r}-0.000 \\
(0.047)\end{array}$ & $\begin{array}{r}-0.001 \\
(0.047)\end{array}$ & $\begin{array}{c}0.013 \\
(0.046)\end{array}$ & $\begin{array}{c}0.015 \\
(0.048)\end{array}$ \\
\hline Market orientation $\times$ political networking & & & $\begin{array}{c}0.063 \\
(0.046)\end{array}$ & $\begin{array}{c}0.045 \\
(0.046)\end{array}$ & $\begin{array}{c}0.047 \\
(0.046)\end{array}$ & $\begin{array}{c}0.019 \\
(0.046)\end{array}$ & $\begin{array}{r}-0.012 \\
(0.054)\end{array}$ \\
\hline Market orientation $\times$ dysfunctional competition & & & & $\begin{array}{c}0.097^{*} \\
(0.045)\end{array}$ & $\begin{array}{c}0.096^{*} \\
(0.045)\end{array}$ & $\begin{array}{l}0.149^{* *} \\
(0.046)\end{array}$ & $\begin{array}{l}0.196^{* *} \\
(0.062)\end{array}$ \\
\hline Political networking $\times$ dysfunctional competition & & & & & $\begin{array}{c}0.020 \\
(0.046)\end{array}$ & $\begin{array}{c}0.008 \\
(0.045)\end{array}$ & $\begin{array}{c}0.004 \\
(0.047)\end{array}$ \\
\hline Market orientation $\times$ political networking $\times$ dysfunctional competition & & & & & & $\begin{array}{c}-0.154^{* *} \\
(0.046)\end{array}$ & $\begin{array}{c}-0.195^{* *} \\
(0.059)\end{array}$ \\
\hline $\mathrm{R}^{2}$ & 0.104 & 0.209 & 0.218 & 0.241 & 0.242 & 0.294 & - \\
\hline $\mathrm{F}$ & $1.888^{+}$ & $3.256^{* * *}$ & $3.175^{* * *}$ & $3.348^{* * *}$ & $3.135^{* * *}$ & $3.816^{* * *}$ & - \\
\hline$\Delta \mathrm{R}^{2}$ & - & $0.105^{* * *}$ & 0.009 & $0.023^{*}$ & 0.001 & $0.052^{* *}$ & - \\
\hline F-test for $\Delta \mathrm{R}^{2}$ & - & $7.108^{* * *}$ & 1.886 & $4.735^{*}$ & 0.190 & $11.388^{* *}$ & - \\
\hline
\end{tabular}

Notes: ${ }^{\mathbf{a}} \mathrm{n}=180 ;{ }^{+} \mathrm{p}<0.10,{ }^{*} \mathrm{p}<0.05,{ }^{* *} \mathrm{p}<0.01,{ }^{* * *} \mathrm{p}<0.001$. Two-tailed test.

${ }^{\mathrm{b}}$ Standard errors of estimated coefficients are reported in parentheses. 
Table 4. Three-way interaction: analysis of the slope differences

\begin{tabular}{lcc}
\hline \hline Pair of slopes & t-value for slope difference & p-value for slope difference \\
\hline (1) and (2) : H2 & -2.135 & 0.034 \\
(1) and (3) & -0.079 & 0.937 \\
(1) and (4) & 2.656 & 0.009 \\
(2) and (3) & 2.055 & 0.042 \\
$(2)$ and (4) & 4.791 & 0.000 \\
$(3)$ and (4) : H1 & 2.735 & 0.007 \\
\hline \hline
\end{tabular}

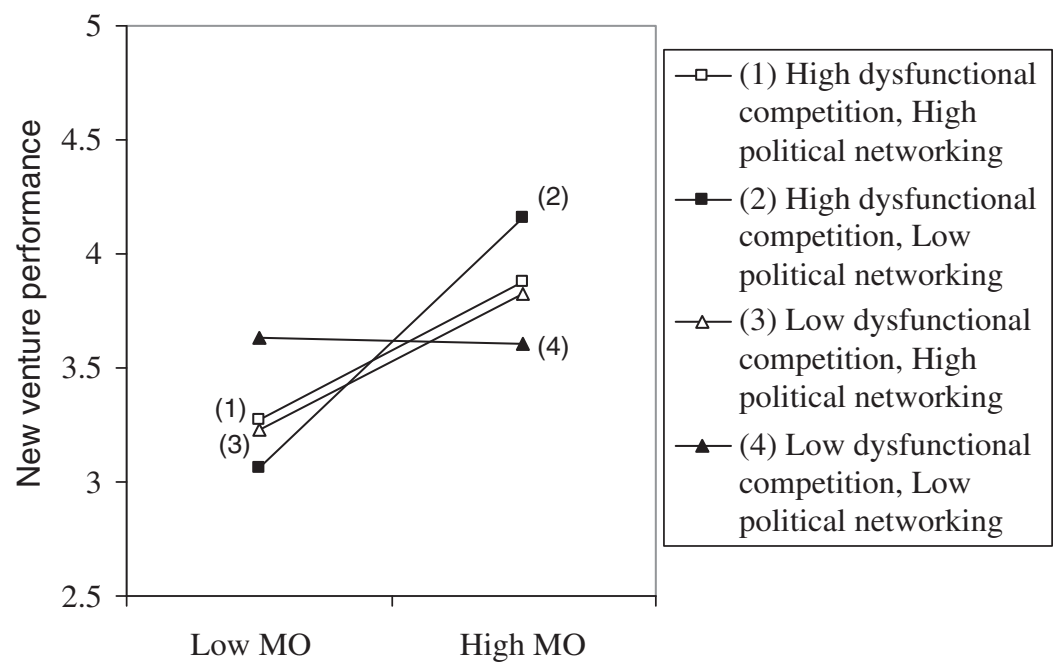

Figure 2. Interaction plots of market orientation (MO), political networking, and dysfunctional competition on new venture performance.

between market orientation and dysfunctional competition (Model 4: $\beta=0.097, p<$ 0.05; $\triangle \mathrm{R}^{2}=0.023^{*}$, F-test for $\left.\triangle \mathrm{R}^{2}=4.735\right)$, revealing that a market-orientation strategy becomes even more important for performance in highly dysfunctional competitive contexts. However, we observe no statistically significant bivariate interaction between market orientation and political networking, in line with our expectation that the influence of hybrid strategies only becomes evident when we take operating conditions into consideration.

In Model 6, we observe that the coefficient of the three-way interaction term is statistically significant $\left(\beta=-0.154, p<0.01 ; \Delta \mathrm{R}^{2}=0.052^{* *}\right.$, F-test for $\Delta \mathrm{R}^{2}=$ 11.388). To illustrate the results more clearly, we plotted the three-way interaction results (Figure 2) and analyzed simple slope differences for each interaction pair (Table 4), using the procedures developed by Aiken and West (1991) and Dawson and Richter (2006). To test H1, we compared slopes 3 and 4 to observe differences between low and high political networking and market orientation at low levels of dysfunctional competition. We observed supportive evidence for our prediction; the difference in slopes is statistically significant. Similarly, we tested H2 by 
comparing slopes 1 and 2 for differences between low and high political networking and market orientation at high levels of dysfunctional competition. As predicted, we observed an opposite relationship: the positive relationship between market orientation and performance weakens as political networking increases, revealing its counterproductive influence. Finally, we compared slopes 2 and 4 to show that at low levels of political networking, the positive direct relationship between market orientation and performance strengthens as dysfunctional competition increases. The statistically significant difference between slopes 2 and 4 further illustrates the benefits of limiting reliance on political networking as dysfunctional competition increases. Notably, the t-test difference between slopes 2 and 4 is the largest among all pairs. Moreover, the probability of performance is highest when ventures have a high emphasis on market orientation, low dependence on political networking, and operate in highly dysfunctional competitive environments (slope 2). These findings confirm our predictions that depending on the level of dysfunctional competition, political networking can either strengthen or weaken the positive direct relationship of market orientation and performance.

\section{Robustness Checks}

To test the robustness of our main findings, we conducted additional diagnostics, ran models with alternate specifications, and investigated threats of endogeneity. First, we looked for possible outliers. We standardized the variables to represent normal distributions; with almost all $\mathrm{Z}$ scores ranging between -3 to 3 , we observed little indication of outliers. ${ }^{[6]}$ Second, in terms of alternate model specifications, we reran our models based on subsamples (using techniques employed in other threeway interaction studies) for privately owned ventures and those with a technology focus (e.g., Stam \& Efling, 2008). In both scenarios, our results remained consistent. We also controlled for ownership in different ways (state-owned, foreign-owned, international joint ventures) as done in prior studies (e.g., Li \& Zhang, 2007; Sheng et al., 2011; Zhou et al., 2008). Again, we found similar results.

We also examined our results for any potential endogeneity issues related to the market-orientation variable. To examine this concern, we employed instrumental variables in a two-stage-least-squares (2SLS) estimation procedure (-ivreg2- in Stata 13.0) for these tests (e.g., Bascle, 2008; Özturan et al., 2014). We report these results in the 2SLS Model (Table 3). The regression coefficients between the 2SLS and OLS results are similar. To conduct this check, we followed procedures conducted in previous studies and identified two instruments - the survey respondent's gender and locus of control (Rotter, 1966), which correlated with the MO variable but not with its error term in our main OLS models. We chose these variables because of their stability over time and their low likelihood of being subject to reverse causality, measurement error, and common method variance bias (e.g., Bascle, 2008; Özturan et al., 2014). The first-stage $F$-statistic $(\mathrm{F}(2,154)=7.110, p<0.01)$ confirmed the relevance of our instruments, while the Sargan statistic (0.105) and $C$-statistic (0.105) 
for the two instruments were all statistically insignificant $(p>0.05)$, confirming the instruments were exogenous to the other variables in the model. The $C$-statistic of 0.105 also showed that each of the independent variables in the overall model were exogenous $(p>0.05)$. To check for possible endogeneity bias from the MO variable, we conducted a Hausman test; the Wu-Hausman $F$-statistic $(\mathrm{F}(1,154)=$ $1.590, p=0.21)$ and Durbin-Wu-Hausman Chi-sq statistic $($ Chi-sq $(1)=1.768, p=$ $0.18)$ were both statistically insignificant $(p>0.10)$, indicating a lack of evidence for endogeneity bias. As one final check, we followed Bascle's (2008) suggestions to test for finite-sample and weak-instrument biases by comparing the 2SLS estimations with Moreira's conditional-likelihood-ratio (Moreira's CLR) estimations. When there is a difference in estimations, Moreira's CLR estimations give robust results regardless of weak instruments (Bascle, 2008: 300). The confidence interval of the conditional likelihood ratio $(-0.11,4.11)$ was statistically insignificant $(p>0.05)$, which meant the two methods produced similar results and finite-sample and weakinstrument biases were not a threat. These tests reassured us that endogeneity from the $\mathrm{MO}$ variable was of minimal concern to our results.

\section{DISGUSSION}

Our work addresses an ongoing question in the transition economies literature: given the assumption that a market-orientation strategy produces positive results in well-functioning market economies and that political networking produces important results in weak institutional regimes, under what conditions do hybrid approaches incorporating both types of strategies lead to better new venture performance? Although some scholars have suggested hybrid strategies should have positive effects on performance, evidence from prior research was inconclusive. We posited instead that the effects of hybrid strategies depend upon a crucial contingency: the extent to which entrepreneurs perceive their industry to have a high level of dysfunctional competition. We argued that a greater emphasis on political networking strengthens the direct positive relationship of marketorientation strategies on performance, but only in contexts where dysfunctional competition is low. In contexts of highly dysfunctional competition, an overemphasis on political-networking strategies is counterproductive and actually diminishes market orientation's positive influence on performance. Our examination of a sample of new ventures in China confirmed our predictions. In the following section, we describe our study's contributions to several aspects of the literature on new venture strategy in transition economies and considerations for future research based on our findings.

\section{Theoretical and Practical Implications}

First, our work advances theories of entrepreneurial growth within transition economies. New ventures in all economies must overcome a variety of competitive 
disadvantages to succeed (Stinchcombe, 1965; Zimmerman and Zeits, 2002); in transition economies, they face additional obstacles caused by weak institutional conditions. Building on Peng's (2003) argument, we provide more clarity regarding how hybrid strategies incorporating both market-oriented and political-networking approaches can improve new ventures' competitive advantages under such conditions. We build on arguments that new ventures grow in different ways, for different reasons, and with different outcomes (Naldi \& Davidsson, 2014). While previous studies emphasized firm growth resulting from the positive relationship between market orientation and performance produced by innovation (e.g., Han et al., 1998), we offer a different set of reasons for potential growth. Specifically, our study demonstrates that new ventures achieve higher performance by choosing hybrid strategies that match the kind of competition they face: [e.g., a) high market orientation and high political networking when dysfunctional competition is low or b) high market orientation and low political networking when dysfunctional competition is high]. These alternative strategies complement established new venture growth principles more commonly associated with mature market-based institutions and offer further evidence that new venture growth is not a uniform phenomenon.

Second, our research advances the ongoing scholarly conversation about the relationship between market-based strategies and new venture performance in transition economies. Scholars typically associate a market-orientation strategy with Western 'market capitalism', wherein new ventures operate through impersonal economic relationships and follow the formal rules of market order (Boisot \& Child, 1996: 622). Although prior studies have explored various boundary conditions regarding the relationship between market orientation and firm performance, those studies were conducted in societies with mature markets and well-developed infrastructures (e.g., Kumar, Subramanian, \& Yauger, 1998; Kumar, Subramanian, \& Strandholm, 2011). Our work adds to this literature by revealing more about the market orientation-performance relationship in weak institutional contexts.

The 'Shanzhai' counterfeit phenomenon in China typifies this form of marketorientation behavior. For example, an entrepreneur described how he dealt with Chinese counterfeits: 'I'd rather throw my money to the engineers, not to my lawyers. You innovate faster than your fakes..... ${ }^{[7]}$ In some situations, innovation may not occur fast enough and so new ventures may opt to imitate popular products at low cost before customer preferences change, a strategy that can be employed with little concern about legal punishment in highly dysfunctional competitive situations. Shanzhai ventures in China are considered '.. the truly customer-centric businesses of China', ${ }^{[8]}$ and 'being in the Shanzhai business is all about speed.... Shanzhai is about selling as many devices as possible before the model goes out of fashion'. ${ }^{[9]}$ Our study empirically grounds these insights and provides a theoretical framework accounting for the complex relationships between market orientation and new 
venture performance in the weak institutional contexts associated with transition economies.

Third, our theory provides a more nuanced assessment of how politicalnetworking strategies moderate the direct relationship between market orientation and new venture performance. Whereas prior studies have found a significant moderating effect of technological and market turbulence (e.g., Han et al., 1998), competitive hostility (e.g., Kumar et al., 1998), and strategic orientation on this association (e.g., Kumar, Subramanian, \& Strandholm, 2011), our findings reveal a negative moderating influence of political networking on the relationship between market orientation and new venture performance in highly dysfunctional competitive contexts, an aspect not closely examined in prior work. Under such conditions, new ventures must put greater emphasis on market orientation to maximize their profits. This strategy requires rapid product or process innovations (e.g., Han et al., 1998), imitation and other opportunistic behaviors (e.g., Li \& Atuahene-Gima, 2001), or a combination of both innovation and opportunism. More broadly, our work provides additional boundary conditions for how and why political networking, as a non-market strategy, can affect new venture performance in transitional economies (Funk \& Hirschman, forthcoming; Marquis \& Reynard, 2015).

Beyond just political networking, our study also contributes more broadly to the ongoing debate regarding the association of network-based strategies and new venture performance. Prior research has shown mixed and inconsistent findings, ranging from relationships that are positive (e.g., Peng \& Luo, 2000), curvilinear (e.g., Li et al., 2008), non-significant (Sheng et al., 2011), and negative (cf. Chen, Chen, \& Huang, 2013; Luo et al., 2012). Other studies have examined the positive and negative aspects of networking on firm performance by focusing on specific boundary conditions inherent in transition economies such as the moderating roles of firm ownership (e.g., Acquaah, 2012), competition and structural uncertainty (e.g., Li et al., 2008), competitive intensity, technological turbulence (e.g., Gu et al., 2008), and government support (e.g., Sheng et al., 2011). To the best of our knowledge, little work besides ours has specifically addressed the question of how political networking moderates the relationship of market orientation and new venture performance.

These theoretical insights have practical implications for venture performance in China and other emerging economies. Our findings mainly have implications for new Chinese ventures and the strategic choices they make for growing their enterprises, but they also apply to other emerging markets where market mechanisms are underdeveloped or where political ties hold greater sway (e.g., Acquaah, 2012: Chung, 2011). New ventures can improve performance by employing hybrid strategies, but the optimal combination of market and politically focused efforts depend on the operating contexts in the sectors where they compete. Further research is required to determine how quickly new ventures recognize what kind of environment they face. 


\section{Limitations and Future Research Directions}

Although we devoted significant care to our study design and analysis, we offer several possibilities for addressing limitations and extending our findings in future research to improve the extent to which our research findings can be generalized (Tsang \& Williams, 2012). First, new investigations should examine the benefits of hybrid strategies using indicators from multiple data sources. In our research, we employed self-reported measures of dysfunctional competition and performance; we suggest future studies search for other third-party and archival measures of these concepts. Second, we used instrumental variables to rule out concerns of endogeneity resulting from possible reciprocal causation. Although our analysis revealed no concerns, future research can move beyond the general limitations of cross-sectional sampling designs and explore the hybrid strategy-performance relationship more carefully using longitudinal approaches to strengthen temporal generalization over time (Tsang \& Williams, 2012). Moreover, new insights could be gained by studying hybrid strategies using a longitudinal design to capture processes that evolve over time as market reforms are adopted and diffused. Third, future studies can analyze how institutional pluralism (such as market and guanxi logics) in China affects new venture strategic choices and behaviors (Du, 2013). Although market logics were introduced relatively recently as a part of China's economic reforms toward market capitalism, guanxi logics have been integral to China's long history and engrained in its cultural tradition (Li et al., 2008; Peng \& Heath, 1996). Based on Tsang and Williams's (2012) framework regarding the generalizability of research findings, our strongest generalization is to the new venture population in Beijing (what they call 'within-population generalization') since the majority of our sample comes from nation's capital and political center. Our arguments and findings can likely be further generalized across populations to other regions in China and to other transition economies, but additional research is required to strengthen such applications. We focused on a single transition economy, and we encourage future research to include more countries representing both developing and developed nations to improve generalizability across different populations. Future studies could also use random samples of industries, chosen to capture those features most likely to be affected by dysfunctional competition. Since 'competition itself may be defined as objective phenomena that all firms will consider the same way or as subjective interpretations of reality' (Chen, 1996: 105), having both objective industry-level and subjective firm-level indicators of dysfunctional competition in a multi-level design may yield a better assessment of its influence on performance.

Although our model explains substantial variance [comparable to the $\mathrm{R}^{2}$ $=0.25$ reported by $\mathrm{Li} \&$ Zhang (2007)], our final model does retain some unexplained variance of new venture performance. While we focused on hybrid strategies (market and political networking) as our primary explanatory variables, other venture characteristics we did not measure could account for the remaining variance. These characteristics include human and financial capital 
(e.g., Cooper Gimeno-Gascon, \& Woo, 1994), top management teams cohesion and conflict (Ensley, Pearson, \& Amason, 2002), strategic decisions besides those we studied, industry structure, and individual-level entrepreneurial characteristics (Kim, Wennberg, \& Croidieu, 2016; Sandberg \& Hofer, 1988). Future research incorporating these characteristics may further reduce the amount of unexplained variance in new venture performance in transition economies.

\section{GONGLUSION}

This study demonstrated the contingent relationships of hybrid market orientationpolitical networking strategies on new venture performance in China, and by extension, other transition economies. As new ventures become established and seek growth opportunities, the effectiveness of their strategies depends on the contexts in which they operate. Besides the challenges of overcoming the liabilities of newness inherent with any new ventures, the level of dysfunctional competition often found in weak institutional environments further complicates the competitive efforts of new ventures. Our work offers new insights into the various combinations of marketand political networking-based strategies yielding better performance outcomes in these operating environments.

\section{NOTES}

We sincerely thank our Senior Editor, Professor Eric Tsang, and two anonymous reviewers for their helpful guidance. We appreciate the constructive comments from Haiyang Li, Liangding Jia, Kersi Antia, seminar participants at Nanjing University, and participants at other conference presentations. We also acknowledge the support from the National Science Foundation of China [Grant \# 71272217, $71472001 ; 71672033]$.

[1] To be consistent with other scholars studying such actions in transition economies, we refer to these efforts as 'political-networking strategies', but they can also be classified under a broader umbrella of corporate political activity, which represent a collection of approaches new ventures can use to improve their performance in non-market venues (Funk \& Hirschman, forthcoming).

[2] We chose to oversample in Beijing for both survey design and practical reasons. From a survey design perspective, we did so to allow for industry diversity while limiting regional variation. We implemented this strategy because it allowed us to generate sufficient variation for the industrybased dysfunctional competition measure. From a practical standpoint, our survey research firm was based in Beijing, which allowed for easier identification and accessibility to local respondents. In supplementary analyses, we ran our models for only the Beijing-based cases; we found results consistent with our main findings.

[3] We found a slightly greater proportion of respondents in terms of location (Beijing-based) and industry (information transmission, computer services, and software ventures). To investigate this further, we added location and industry dummy variables in our multivariate analyses. Both variables produced statistically insignificant results.

[4] Model fit is considered good when the RMSEA values are less than 0.08 and the other fit statistics are greater than 0.90 (Bollen, 1989).

[5] As for the additional sampling in other parts of China, we focused on eight provinces and two special municipalities: Guangdong, Shanghai, Jiangsu, Hunan, Shandong, Tianjin, Hebei, Liaoning, Heilongjiang, and Jilin. Although the survey firm attempted to achieve a higher response rate in these areas outside Beijing, we did not have a sufficient number of cases to allow for a more comprehensive regional analysis beyond including a binary variable for a Beijing-based venture. 
[6] We observed one case with a Z-score of -3.055 (for the new venture performance variable). We reran our models after deleting it; our results remained consistent.

[7] Quote from http://www.bbc.co.uk/news/business-21407916

[8] Quote from http://designmind.frogdesign.com/articles/shanzhai-s-role-in-innovation-strategy. html

[9] Quote from http://techrice.com/2011/06/20/shanzhai-factory-life-the-making-of-amotoloba/

\section{APPENDIX I}

\section{A.1. Measures Used in the Study}

New Venture Performance (Source: Li \& Atuahene-Gima, 2001), measured on a five-point scale, with $1=$ 'worse' and $5=$ 'much better' $(\alpha=0.82$, composite reliability $=0.83)$

Relative to your principal competitors, rate your firm performance over the last three years on: return on sales, profit growth, overall efficiency of operations, sales growth, market share growth, and firm's overall reputation.

Market Orientation (Source: Narver \& Slater, 1990), measured on five-point scale, with $1=$ 'strongly disagree' and $5=$ 'strongly agree' $(\alpha=0.89$, composite reliability $=0.88)$

For each of the following questions, please indicate the response that most closely describes your organization.

1. We respond rapidly to competitive actions.

2. Top management regularly discusses competitors' strength and weaknesses.

3. Customers are targeted when we have an opportunity for competitive advantage.

4. Our business objectives are driven by customer satisfaction.

5. We closely monitor and assess our level of commitment in serving customers' needs.

6. Our competitive advantage is based on understanding customers' needs.

7. We frequently measure customer satisfaction.

8. We pay close attention to after-sales service.

9. Our top managers from each business function regularly visit customers.

10. Our managers understand how employees can contribute to value of customers.

11. We share resources with other business units.

Political Networking (Source: Li \& Atuahene-Gima, 2001), measured on a five-point scale: $1=$ 'to no extent' and $5=$ 'to a great extent' $(\alpha=0.75$, composite reliability $=0.78)$

Please indicate the extent to which top management of your firm over the last three years have:

1. Spent much effort in cultivating personal connections with officials of government and its agencies.

2. Devoted substantial resources to maintain good relationships with officials of administrative agencies.

3. Spent a lot of money on building relations with the top officials in government.

Dysfunctional Competition (Source: Li \& Atuahene-Gima, 2001), measured on a five-point scale: $1=$ 'to no extent' and $5=$ 'to a great extent' $(\alpha=0.71$, composite reliability $=0.71)$

Indicate the extent to which your principal industry has experienced the following in the last 3 years:

1. Counterfeiting of your firm's own products and trademarks by other firms.

2. Ineffective market competitive laws to protect your firm's intellectual property.

3. Increased unfair competitive practices by other firms in the industry. 
Environmental Hostility (Source: Miller, 1987, $\alpha=0.60$, composite reliability $=0.73$ )

1. Market activities of your key competitors over the past 3 years:

(1) have become far more hostile

(7) have become less hostile

2. Market activities of your key competitors over the past 3 years:

(1) now affect the firm in many more areas (pricing, marketing, delivery, service, production, quality, etc.)

(7) now affect the firm in far fewer areas

3. Legal, political and economic constraints (e.g. government regulations):

(1) have proliferated greatly over the past 3 years

(7) almost no change

Entrepreneurship Orientation: 'the processes, structures, and behaviors of firms that are characterized by innovativeness, proactiveness, and risk taking’ (Source: Covin \& Slevin, 1989), anchored at 1 and 7 as two end points $(\alpha=0.69)$

1. In general, the top managers of my company favor:

(1) a strong emphasis on the marketing of tried and true products or services.

(7) a strong emphasis on R\&D technology leadership and innovations.

2. How many new lines of products or services has your company marketed during the past 3 years?

(1) no new lines or products or services.

(7) very many new lines of products and service.

3. In dealing with its competition, my company:

(1) typically responds to actions which competitors initiate.

(7) typically initiates actions to which competition then respond.

4. In dealing with its competition, my company:

(1) is very seldom the first business to introduce new products or services, administrative techniques, operating technologies, etc.

(7) is very often the first business to introduce new products or services, administrative techniques, operating technologies, etc.

5. In dealing with its competition, my company:

(1) typically seeks to avoid competitive clashes, preferring a 'live-and-let-live' posture.

(7) typically adopts a very competitive, 'undo-the-competition' posture.

6. In general, the top managers of my company have:

(1) a strong proclivity for low risk projects (with normal and certain rates of return).

(7) a strong proclivity for high-risk projects (with chances of very high returns).

7. In general, the top managers of my company believe that:

(1) owing to the nature of the environment, it is best to explore it gradually via cautious, incremental behavior.

(7) owing to the nature of the environment, bold, wide-ranging acts are necessary to achieve the firm's objectives.

8. When confronted with decision-making situations involving uncertainty, my firm:

(1) typically adopts a cautious, 'wait-and-see' posture in order to minimize the probability of making costly decisions.

(7) typically adopts a bold, aggressive posture in order to maximize the probability of exploiting potential opportunities.

Institutional Support: 'reflects the extent to which administrative institutions (such as government departments) provide support for firms in order to reduce the adverse effects of the inadequate institutional infrastructure in the transition process (Source: Li \& AtuaheneGima, 2001), measured on a five-point scale: $1=$ 'to no extent' and $5=$ 'to a great extent' $(\alpha=0.76)$ 
Please indicate the extent to which in the last three years government and its agencies have:

1. Implemented policies and programs that have been beneficial to your firm's operations.

2. Provided needed technology information and technical support to your firm.

3. Played a significant role in providing financial support for your firm.

4. Helped your firm to obtain licenses for imports of technology, manufacturing and other equipment.

\section{A.2. Measurement properties of key variables}

\begin{tabular}{lccc}
\hline \hline $\begin{array}{l}\text { Construct and indicators } \\
\text { loadings }\end{array}$ & Reliability & $\begin{array}{c}\text { Variance-extracted } \\
\text { Estimate }\end{array}$ \\
\hline Market orientation & $0.88^{\mathrm{a}}$ & & 0.72 \\
$\quad$ Competitor orientation & 0.74 & 0.55 & \\
Customer orientation & 0.88 & 0.77 & \\
$\quad$ Inter-functional & 0.91 & 0.83 & 0.56 \\
orientation & & & \\
Political networking & 0.82 & $0.78^{\mathrm{a}}$ & \\
$\quad$ Indicator 1 & 0.88 & 0.67 & 0.46 \\
Indicator 2 & 0.47 & 0.23 & \\
Indicator 3 & & $0.71^{\mathrm{a}}$ & \\
Dysfunctional competition & 0.61 & 0.38 & \\
Indicator 1 & 0.62 & 0.39 & \\
Indicator 2 & 0.79 & 0.61 & \\
$\quad$ Indicator 3 & & $0.83^{\mathrm{a}}$ & \\
New venture performance & 0.78 & 0.60 & \\
Indicator 1 & 0.86 & 0.73 & \\
Indicator 2 & 0.73 & 0.53 & \\
Indicator 3 & &
\end{tabular}

${ }^{\mathrm{a}}$ Composite reliability for the entire scale.

\section{REFERENCES}

Acquaah, M. 2012. Social networking relationships, firm-specific managerial experience and firm performance in a transition economy: A comparative analysis of family owned and nonfamily firms. Strategic Management Journal, 33(10): 1215-1228.

Aiken, L. S., \& West, S. G. 1991. Multiple regression: Testing and interpreting interactions. London: Sage.

Aldrich, H. E., \& Fiol, C. M. 1994. Fools rush in? The institutional context of industry creation. Academy of Management Revieze, 19(4): 645-670.

Aldrich, H. E., \& Ruef, M. 2006. Organizations evolving. London: Sage.

Baruch, Y., \& Holtom, B. C. 2008. Survey response rate levels and trends in organizational research. Human Relations, 61(8): 1139-1160.

Bascle, G. 2008. Controlling for endogeneity with instrumental variables in strategic management research. Strategic Organization, 6(3): 285-327.

Boisot, M., \& Child, J. 1996. From fiefs to clans and network capitalism: Explaining China's emerging economic order. Administrative Science Quarterly, 41(4): 600-628.

Bollen, K. 1989. Structural equations zith latent variables. New York: Wiley.

Bradley, S. W., Aldrich, H. E., Shepherd, D. A., \& Wiklund, J. 2011. Resources, environmental changes, and survival: Asymmetric paths of young independent and subsidiary organizations. Strategic Management Journal, 32(5): 486-509. 
Brislin, R. W. 1980. Translation and content analysis of oral and written material. In H. C. Triandis \& J. W. Berry (Eds.), Handbook of cross-cultural psychology: 389-444. Boston: Allyn Bacon.

Chen, M. 1996. Competitor analysis and interfirm rivalry: Toward a theoretical integration. Academy of Management Revieze, 21(1): 100-134.

Chen, C. C., Chen, X. P., \& Huang, S. 2013. Chinese guanxi: An integrative review and new directions for future research. Management and Organization Revieze, 9(1): 167-207.

Chung, H. F. 2011. Market orientation, guanxi, and business performance. Industrial Marketing Management, 40(4): 522-533.

Cooper, A. C., Gimeno-Gascon, F. J., \& Woo, G. Y. 1994. Initial human and financial capital as predictors of new venture performance. Journal of Business Venturing, 9(5): 37 1-395.

Dawson, J. F., \& Richter, A. W. 2006. Probing three-way interactions in moderated multiple regression: Development and application of a slope difference test.Journal of Applied Psychology, 91(4): 917-926.

Delmar, F., \& Shane, S. 2004. Legitimating first: Organizing activities and the survival of new ventures. Journal of Business Venturing, 19(3): 385-410.

Du, Y. Z. 2013. Institutional pluralism and new venture growth in China: A three way interaction. Paper presented at the Annual Meeting of the Academy of Management (AOM), Orlando, August 2013.

Edwards, J. R. 2003. Construct validation in organizational behavior research. In J. Greenberg (Ed.), Organizational behavior: The state of the science (2nd ed.): 327-371. Mahwah, NJ: Erlbaum.

Eisenhardt, K. M. 1989. Making fast strategic decisions in high-velocity environments. Academy of Management Journal, 32(3): 543-576.

Ensley, M. D., Pearson, A. W., \& Amason, A. C. 2002. Understanding the dynamics of new venture top management teams: Cohesion, conflict, and new venture performance. Journal of Business Venturing, 17(4): 365-386.

Fan, G., Wang, X., \& Zhu, H. 2010. NERI index of marketization of China's Provinces 2009 report. Beijing: Economic Science Press. (In Chinese).

Funk, R., \& Hirschman, D. 2015. Beyond nonmarket strategy: Market actions as corporate political activity. Academy of Management Reviez. DOI: 10.5465/amr.2013.0178.

Fornell, C., \& Larcker, D. F. 1981. Evaluating structural equation models with unobservable variables and measurement error. Journal of Marketing Research, 18(1): 39-50.

Gu, F. F., Hung, K., \& Tse, D. K. 2008. When does guanxi matter? Issues of capitalization and its dark sides. Journal of Marketing, 72(4): 12-28.

Guo, C., \& Miller, J. K. 2010. Guanxi dynamics and entrepreneurial firm creation and development in China. Management and Organization Revieze, 6(2): 267-291.

Hair, J. F., Anderson, R. E., Tatham, R. L., \& Black, W. C. 1998. Multivariate data analysis (5th ed.). New Jersey: Prentice Hall.

Han, J. K., Kim, N., \& Srivastava, R. K. 1998. Market orientation and organizational performance: Is innovation a missing link? Journal of Marketing, 62(4): 30-45.

Hoskisson, R. E., Eden, L., Lau, C. M., \& Wright, M. 2000. Strategy in emerging economies. Academy of Management Journal, 43(3): 249-267.

Hu, J. L., Wan, H. T., \& Zhu, H. 2011. The business model of a shanzhai mobile phone firm in China. Australian Journal of Business and Management Research, 1(3): 52-62.

Jaworski, B. J., \& Kohli, A. K. 1993. Market orientation: Antecedents and consequences.Journal of Marketing, 57(3): 53-70.

Jia, L. D., You, S. Y., \& Du, Y. Z. 2012. Chinese context and theoretical contributions to management and organization research: A three-decade review. Management and Organization Revieze, 8(1): 173-209.

Kenny, D. A. 2012. Multiple latent variable models: Confirmatory factor analysis. [Cited 25 January 2016.] Available from URL: http://www.davidakenny.net/cm/mfactor.htm

Kim, P. H., \& Li, M. 2014. Seeking assurances when taking action: Legal systems, social trust, and starting businesses in emerging economies. Organization Studies, 35(3): 359-391.

Kim, P. H., \& Wennberg, K., \& Croidieu, G. 2016. Untapped Riches of Meso-Level Applications in Multilevel Entrepreneurship Mechanisms. Academy of Management Perspectives.

Kumar, K., Subramanian, R., \& Strandholm, K. 2011. Market orientation and performance: Does organizational strategy matter? Journal of Applied Business Research, 18(1): $37-49$. 
Kumar, K., Subramanian, R., \& Yauger, C. 1998. Examining the market orientation-performance relationship: A context-specific study.Journal of Management, 24(2): 201-233.

Li, H. Y. 2001. How does new venture strategy matter in the environment-performance relationship? Journal of High Technology Management Research, 12(2): 183-204.

Li, H. Y., \& Atuahene-Gima, K. 2001. Product innovation strategy and performance of new technology ventures in China. Academy of Management Journal, 44(6): 1123-1134.

Li, H. Y., \& Zhang, Y. 2007. The role of managers' political networking and functional experience in new-venture performance: Evidence from China's transition economy. Strategic Management Journal, 28(8): 791-804.

Li, J.J., Poppo, L., \& Zhou, K. Z. 2008. Do managerial ties in China always produce value? Competition, uncertainty, and domestic vs. foreign firms. Strategic Management Journal, 29(4): 383-400.

Li, J. T., \& Qian, C. 2013. Principal-principal conflicts under weak institutions: A study of corporate takeovers in China. Strategic Management Journal, 34(4): 498-508.

Lieberman, M. B, \& Montgomery, D. B. 1998. First-mover (dis)advantages: Retrospective and link with the resource-based view. Strategic Management Journal, 19(12): 1111-1125.

Lindell, M. K., \& Whitney, D. J. 2001. Accounting for common method variance in cross-sectional research designs. Journal of Applied Psychology, 86(1): 114-121.

Luo, Y. 2003. Industrial dynamics and managerial networking in an emerging market: The case of China. Strategic Management Journal, 24(13): 1315-1327.

Luo, Y., Huang, Y, \& Wang, S. L. 2012. Guanxi and organizational performance: A meta-analysis. Management and Organization Revieze, 8(1): 139-172.

Ma, D. 2015. Social belonging and economic action: Affection-based social circles in the creation of private entrepreneurship. Social Forces, 94(1): 87-1 14.

Marquis, C., \& Raynard, M. 2015. Institutional strategies in emerging markets. The Academy of Management Annals, 9(1): 291-335.

Malhotra, N. K., Kim, S. S., \& Patil, A. 2006. Common method variance in IS research: A comparison of alternative approaches and a reanalysis of past research. Management Science, 52(12): 1865-1883.

McDougall, P. P., Covin, J. G., Robinson, R. B., \& Herron, L. 1994. The effects of industry growth and strategic breadth on new venture performance and strategy content. Strategic Management Journal, 15(7): 537-554.

Miller, D. 1987. The structural and environmental correlates of business strategy. Strategic Management Journal, 8(1): 55-76.

Mitchell, W., \& Singh, K. 1996. Survival of businesses using collaborative relationships to commercialize complex goods. Strategic Management Journal, 17(3): 169-195.

Nadkarni, S., \& Narayanan, V. K. 2007. Strategic schemas, strategic flexibility and firm performance: The moderating role of industry clockspeed. Strategic Management Journal, 28(3): 243270.

Naldi, L., \& Davidsson, P. 2014. Entrepreneurial growth: The role of international knowledge acquisition as moderated by firm age. Journal of Business Venturing, 29(5): $687-703$.

Narver,J. C., \& Slater, S. F. 1990. The effect of a market orientation on business profitability.Journal of Marketing, 54(4): 20-35.

Nee, V. 1989. A theory of market transition: From redistribution to markets in state socialism. American Sociological Revieze, 54(5): 663-681.

Nee, V. 1992. Organizational dynamics of market transition: Hybrid forms, property rights, and mixed economy in China. Administrative Science Quarterly, 37(1): 1-27.

Okhmatovskiy, I. 2010. Performance implications of ties to the government and SOEs: A political embeddedness perspective. Journal of Management Studies, 47(6): 1020-1047.

Özturan, P., Özsomer, A., \& Pieters, R. 2014. The role of market orientation in advertising spending during economic collapse: The case of Turkey in 2001.Journal of Marketing Research, 51(2): 139-152.

Peng, M. W. 2003. Institutional transitions and strategic choices. Academy of Management Revieze, 28(2): 275-296.

Peng, M. W., \& Heath, P. 1996. The growth of the firm in planned economies in transition: Institutions, organizations, and strategic choices. Academy of Management Revieze, 21(2): $492-528$. 
Peng, M. W., \& Luo, Y. 2000. Managerial ties and firm performance in a transition economy: The nature of a micromacro link. Academy of Management Journal, 43(3): 486-501.

Peng, M. W., Wang, D. Y. L., \& Jiang, Y. 2008. An institution-based view of international business strategy: A focus on emerging economies. Journal of International Business Studies, 39(5): 920-936.

Podsakoff, P. M., MacKenzie, S. B., Lee, J. Y., \& Podsakoff, N. P. 2003. Common method biases in behavioral research: A critical review of the literature and recommended remedies.Journal of Applied Psychology, 88(5): 879-903.

Podsakoff, P., \& Organ, D. 1986. Self reports in organizational leader reward and punishment behavior and research: Problems and prospects.Journal of Management, 12(4): 531-544.

Porter, M. 1985. Competitive advantage. New York: Free Press.

Reinholt, M., Pedersen, T, \& Foss, N. 2011. Why a central network position isn't enough: The role of motivation and ability for knowledge sharing in employees networks. Academy of Management Journal, 54(6): 1277-1297.

Rotter, J. B. 1966. Generalized expectancies for internal versus external control of reinforcement. Psychological monographs: General and applied, 80(1): 1-28.

Sandberg, W. R., \& Hofer, C. W. 1988. Improving new venture performance: The role of strategy, industry structure, and the entrepreneur.Journal of Business Venturing, 2(1): 5-28.

Shane, S., \& Cable, D. 2002. Network ties, reputation, and the financing of new ventures. Management Science, 48(3): 364-381.

Sheng, S., Zhou, K. Z., \& Li, J. J. 2011. The effects of business and political ties on firm performance: Evidence from China.Journal of Marketing, 75(1): 1-15.

Shleifer, A., \& Vishny, R. 1998. The grabbing hand: Government pathologies and their cures. Cambridge, MA: Harvard University Press.

Siemsen, E., Roth, A., \& Oliveira, P. 2010. Common method bias in regression models with linear, quadratic, and interaction effects. Organizational Research Methods, 13(3): 456-476.

Spector, P. E. 2006. Method variance in organizational research: Truth or urban legend? Organizational Research Methods, 9(2): 221-232.

Stam, W., \& Elfring, T. 2008. Entrepreneurial orientation and new venture performance: The moderating role of intra-and extra-industry social capital. Academy of Management Journal, $51(1)$ : 97-111.

Stinchcombe, A. L. 1965. Organizations and social structure. In J.G. March (Ed.), Handbook of organizations: 140-200. Chicago: Rand-McNally.

Sun, P., Mellahi, K., \& Wright, M. 2012. The contingent value of corporate political ties. Academy of Management Perspectives, 26(3): 68-82.

Tan, J., \& Litsschert, R. J. 1994. Environment-strategy relationship and its performance implications: An empirical study of the Chinese electronics industry. Strategic Management Journal, 15(1): $1-20$.

Teece, D. J. 1986. Profiting from technological innovation: Implications for integration, collaboration, licensing and public policy. Research Policy, 15(6): 285-305.

Tsang, E. W. K. 1996. In search of legitimacy: The private entrepreneur in China. Entrepreneurship Theory and Practice, 21(1): 21-30.

Tsang, E. W., \& Williams, J. N. 2012. Generalization and induction: Misconceptions, clarifications, and a classification of induction. MIS Quarterly, 36(3): 729-748.

Tuggle, F. D., \& Gerwin, D. 1980. An information processing model of organizational perception, strategy and choice. Management Science, 26(6): 575-592.

Uzzi, B. 1997. Social structure and competition in interfirm networks: The paradox of embeddedness. Administrative Science Quarterly, 42(1): 35-67.

Wang, H., Law, K. S., Hackett, R. D., Wang, D., \& Chen, Z. X. 2005. Leader-member exchange as a mediator of the relationship between transformational leadership and followers' performance and organizational citizenship behavior. Academy of Management Journal, 48(3): 420-432.

Xin, K. R., \& Pearce, J. L. 1996. Guanxi: Connections as substitutes for formal institutional support. Academy of Management Journal, 39(6): 1641-1658.

Yang, K. M. 2004. Institutional holes and entrepreneurship in China. Sociological Revieze, 52(3): 371-389.

Zhang, Y., \& Li, H. Y. 2010. Innovation search of new ventures in a technology cluster: The role of ties with service intermediaries. Strategic Management Journal, 31(1): 88-109.

Zhou, K. Z., Li, J. J., Zhou, N., \& Su, C. 2008. Market orientation, job satisfaction, product quality, and firm performance: Evidence from China. Strategic Management Journal, 29(9): 985-1000. 
Zimmerman, M., \& Zeitz, G. 2002. Beyond survival: Achieving new venture growth by building legitimacy. Academy of Management Revieze, 27(3): 414-431.

Yunzhou Du (duyunzhou_2000@sina.com) is a Professor of Management at the School of Economics \& Management, Southeast University, and a former Professor at Anhui University of Finance \& Economics. He received his $\mathrm{PhD}$ in Entrepreneurship and Innovation from Nankai University, China, did his visiting scholar research at University of North Carolina at Chapel Hill, USA, and post-doctoral research at Nanjing University, China. His research interests include institution, entrepreneurship, organizational decline, Chinese culture and innovation, and international business.

Phillip H. Kim (pkim1@babson.edu) is Associate Professor of Entrepreneurship at Babson College, USA. His research broadly examines how entrepreneurs and nascent firms secure resources and legitimacy in emergent fields. His insights on these themes have been published in leading entrepreneurship and management journals.

Howard E. Aldrich (Howard_aldrich@unc.edu) is Kenan Professor of Sociology; Adjunct Professor of Business at the University of North Carolina, Chapel Hill; Faculty Research Associate at the Department of Strategy \& Entrepreneurship, Fuqua School of Business, Duke University; and Fellow, Sidney Sussex College, Cambridge University. He is a Faculty Fellow of the Center for Study of Economy and Society, Cornell University. His main research interests are entrepreneurship, entrepreneurial team formation, gender and entrepreneurship, and evolutionary theory.

Manuscript received: September 17, 2014

Final version accepted: July 1, 2016 (number of revisions - 3)

Accepted by: $\quad$ Eric W. K. Tsang 